\title{
Content Marketing Training and Assistance to Micro Enterprises from Rumah Kreatif BUMN-Telkom Community in Malang Regency
}

\author{
Moch Fuad Nasvian*, Radityo Widiatmojo, Aditya Dwi Putra Bhakti, Zen Amirudin \\ Communication Department, University of Muhammadiyah Malang, Raya Tlogomas 246, Malang, \\ Indonesia, 65144 \\ Correspondence: Moch Fuad Nasvian (nasvian@umm.ac.id) \\ Received: 26 November 2020 - Revised: 10 January 2021 - Accepted: 11 January 2021
}

\begin{abstract}
The Covid-19 pandemic in Indonesia forces people to have different behaviours, both socially and economically. This epidemic has made Indonesians' shopping behaviour change; online shopping and cashless transactions have increased rapidly. Micro, Small, and Medium Enterprises (MSMEs) in Indonesia has left behind this consumer behaviour change. The BUMN Creative House (RKB) is a government effort to improve MSMEs' quality in products, marketing, and funding. Regularly, RKB provides its members with training, workshop but cannot afford to assist their new knowledge. Telkom Indonesia manages the RKB in Malang Regency. This service activity is in the form of training and mentoring for MSMEs who are also partners of the RKB. The training lasts for three weeks, with tiered materials about content marketing and one month of assistance after the last session training to deepen their skills to help MSMEs setup their new digital marketing technique and deepen their skills. From this program, we found that (1) MSMEs digital literacy is varied depending on their age; (2) Greater Malang MSMEs is slow to adapt in new digital marketing technique, they even scared to try it, because even after one month of assistance, only 3 out of 15 businesses can advertise on the Facebook Platform.
\end{abstract}

Keywords: MSMEs, content marketing, generation

Citation Format: Nasvian, M.F., Widiatmojo, R., Bhakti, A.D.P., \& Amirudin, Z. (2021). Content Marketing Training and Assistance to Micro Enterprises from Rumah Kreatif Bumn-Telkom Community in Malang Regency. Journal of Community Practice and Social Welfare, 1(1), 10-22. 


\section{INTRODUCTION}

During the Indonesian Reformation era, the economy was built on a democratic economic system (Riveong \& Rachmad, 2018). A democratic economic system's main components are human resources as consumers, workers, and businesspersons. The democratic economic system provides employment opportunities and seeks for the public to achieve increased prosperity evenly and equitably. Specifically, this requires efforts to improve the local economy in various programs, including the development of Micro Small Medium Scales Enterprises (MSMEs).

In Indonesia, MSMEs are an important business sector. SMEs dominated 99.99\% of the existing business sector in the country. MSMEs can survive the economic crisis in 1998 because it requires little capital. In addition, they tend to use their capital, and as a result, they do not rely on the fluctuation of foreign currency. As a matter of fact, after the crisis, MSME is multiplying (LPPI and BI, 2015). Micro, Small, and Medium Enterprises are household-scale industries that hire between 1 and 19 workers for Small Businesses or between 20 and 99 workers for Medium Enterprises. Currently, MSMEs can absorb $97.16 \%$ of the total Industrial workforce in Indonesia (107.66 million). The rest is working in Large Enterprises (Badan Pusat Statistik, 2010). The increasing number of MSMEs generates more money for state revenues. Between 2007 and 2012, the national GDP increased by $18.33 \%$ per annum from $2,107,868$ billion to $4,869,568$ billion rupiahs. These show how vital MSMEs are for the national GDP (Kurniawati et al., 2019). Various positive impacts of MSMEs make it a very strategic business sector to develop.

The Covid-19 pandemic currently occurring inevitably affects various sectors. At the global economic level, the Covid-19 pandemic has a significant impact on the nationstate's domestic economy and MSMEs' existence. The Organization for Economic Cooperation and Development (OECD) report states that this pandemic has implications for the threat of a significant economic crisis marked by the cessation of production activities in many countries, falling levels of public consumption, loss of consumer confidence, falling stock markets which ultimately leads to uncertainty (OECD Secretary General, 2020).

In this pandemic situation, according to Kemenkop UKM (Kementerian Koperasi dan Usaha Kecil dan Menengah), there are around 37,000 MSMEs who report that they are very seriously affected by this pandemic, marked by around 56 percent reported a decrease in sales, 22 percent reported problems in the aspect of the financing, 15 percent reported 
problems with the distribution of goods, and 4 percent reported difficulty obtaining raw materials (Rahman, 2020). The problems above are also increasingly widespread when linked to the large-scale social restrictions (PSBB) policy implemented in Indonesia's several regions. Referring to the Minister of Health Regulation No. 9/2020 concerning PSBB Guidelines for the Acceleration of Handling Covid-19, PSBB includes restrictions on certain activities of residents in an area suspected of being infected with Covid-19, including restrictions on the movement of people and goods for a particular province or regency/city to prevent the spread of the virus. These restrictions are carried out through school and work vacations, restrictions on religious activities, and restrictions on public places or facilities. The Ministry of Finance analyses that with the existence of PSBB, economic activities, especially production, distribution, and sales, will experience disruption, which will further contribute to the performance of MSMEs and the national economy (Djatmiko \& Pudyastiwi, 2020).

The data said that Indonesia's Internet user is $64 \%$ of the total population (Kemp, 2020). It means that Covid-19 PSBB should have no significant impact on the Indonesian economy, except in distribution activity. Unfortunately, $99 \%$ of the internet activity by Indonesian are watching YouTube, instead of using it for making money. Whereas the tendency of Indonesian people to shop online is getting higher.

Generally, travellers visit the greater Malang to seek various natural and artificial tourist attractions and enjoy local specialties. This condition makes MSMEs in greater Malang mostly relying on their sales from tourism. The MSMEs were pessimistic about selling their product in a regular store because they did not trust their product to compete with major manufacturers. With the enactment of the covid-19 national lockdown, these micro industries have lost most of their potential sales. In the pandemic Covid-19, global E-commerce gains multiple transactions (Donthu \& Gustafsson, 2020); it would be good for MSMEs to place their digital product because the momentum is there.

In this condition, this is the perfect time for Indonesian MSMEs to start their digital marketing activity. The best platform for digital marketing MSMEs is WhatsApp and Facebook, as their popularity very high, above 80\% (Priambada, 2017; Kemp, 2020). YouTube is still the most used social media in Indonesia, but it needs effort, and it does not suit the characteristic of Indonesian MSMEs (Kurniawati et al., 2019).

This community service helps the MSMEs community, under one of the RKB (Rumah Kreatif BUMN) or BUMN creative houses in Malang regency, to understand 
digital marketing, especially in content marketing. Content marketing is an activity on social media to influence online users and entice them to purchase their products or services (Hajarian et al., 2020). As a member of MSMEs RKB Telkom Malang Regency growing, they do not have enough human resources to train and assist their new skillset. As part of State-owned enterprises, Telkom also restricts its employees' movement due to the Covid-19 pandemic. UMM's community service helps 15 newest members of MSMEs RKB Telkom Malang Regency to train and assist them primarily to make content and promote in Facebook ads.

\section{PROBLEMS}

The Covid-19 pandemic has a significant impact on the nation-state's domestic economy and MSMEs' existence. Indonesia's Internet user is $64 \%$ of the total population (Kemp, 2020). It means that Covid-19 PSBB should have no significant impact on the Indonesian economy, except in distribution activity, which means that MSMEs can use it as a solution to sell their product. The problem is that MSMEs in Greater Malang are inadequate to join the digital market because their ability is finite; most micro-businesses are managed by the owner only and have limited capital, so they need help to acquire digital marketing content marketing skills.

\section{IMPLEMENTATION METHOD}

For helping MSMEs, especially those under the Telkom Community, the University of Muhammadiyah team assesses what is faced by the micro-enterprises during the Covid19 pandemic. The assessment of the newest member of Telkom MSMEs community shows that they do not know how to sell and promote their product online. The community service team proposes two monthly training consisting of tiered materials, around three to five hours per session ( 9 am $-1 \mathrm{pm}$ ), and active assistance via Whatsapp group.

In the first week, 15 July 2020, participants learned about Creating Videos and Developing Promotional Language. The trainee made a promotional video using their smartphone and product photos, with Kinemaster application, to gain more Facebook audience awareness. Good content is a how-to present visual and perfect word to capture direct emotion to the audience. Obtaining awareness on social media will be more comfortable with a catchy caption related to product and audience current condition. The trainer also practices the participant to write powerful yet straightforward phrases to perfection their content marketing. These two main content marketing activities need more 
practice to master it; trainers use the WhatsApp group to monitor participant skill development the whole week during 15-22 July 2020.

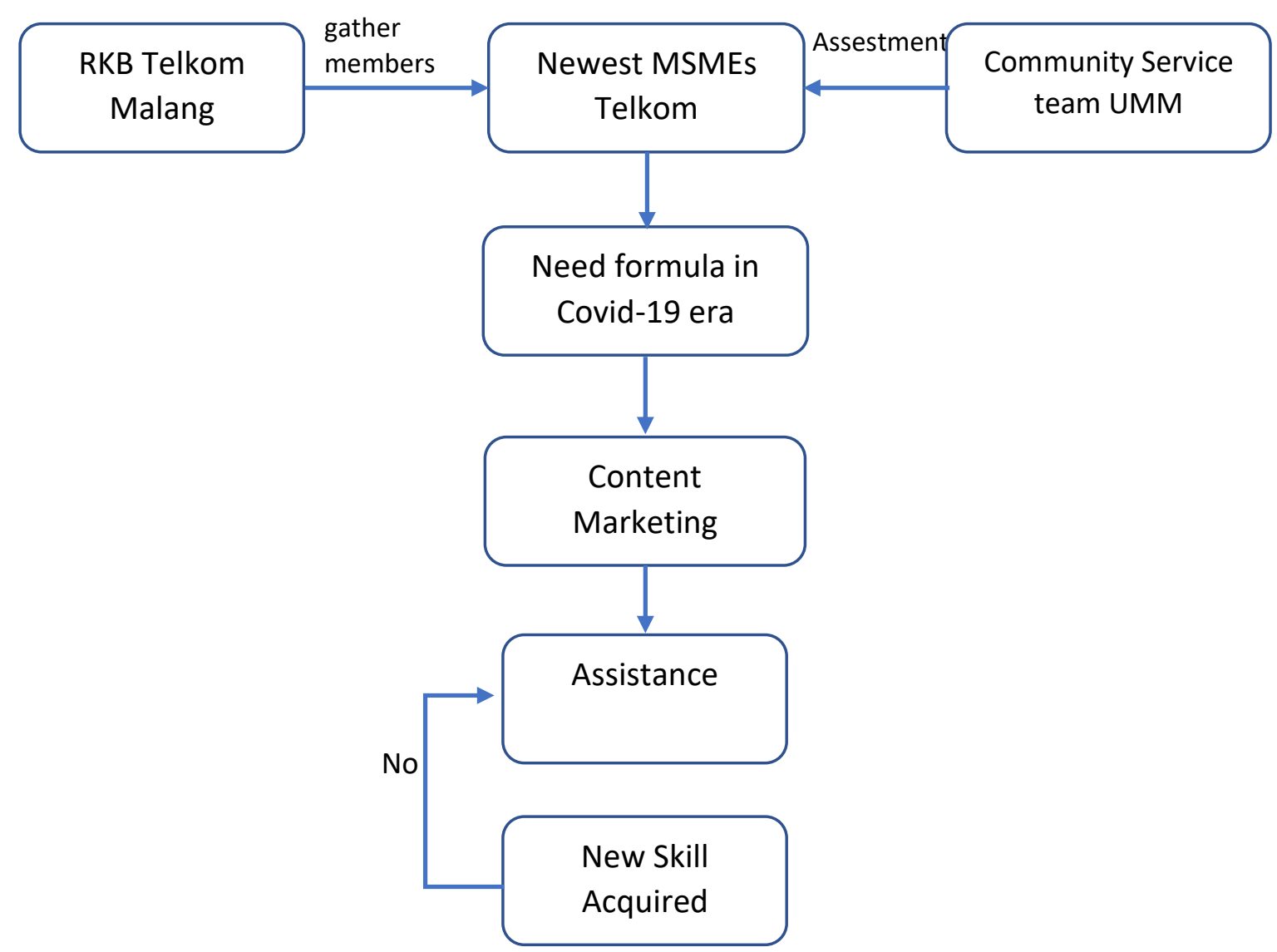

Figure 1. Program flow of community services MSMEs RKB Telkom Malang Regency.

The next material to share with participants, on 22 July 2020, is about digital marketing and advertising strategies on Facebook, especially placing an advertisement on Facebook. Placing an advertisement on Facebook means that the trainee content will be shown on Facebook and Instagram according to the target audience set. Placing a Facebook advertisement is not difficult but needs a detailed understanding of the MSMEs target market; it consists of demographic, socioeconomic status, behavior, location, and even the types of the target audience's job. To support trainee on Facebook advertising placement, UMM's community service team paid their first three days of advertising, that amount Rp.50.000,- per person. 


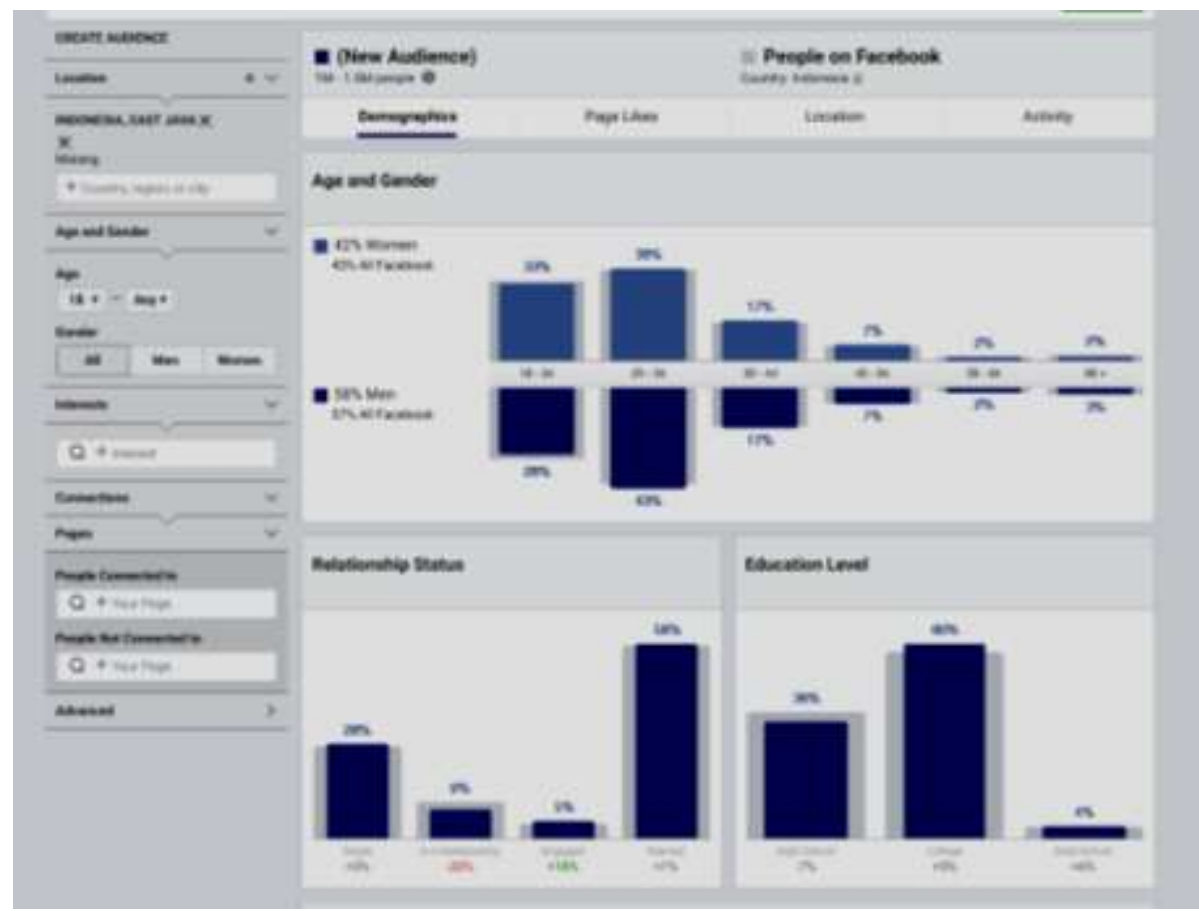

Figure 2. Facebook audience Insight to set up an advertisement.

The third-week training material, 29 July 2020, is to learn to read data on advertising results and compile more effective promotional messages. Mastering producing good content marketing takes time. Moreover, understanding the desired target market also requires several market research; in the third meeting, trainers give participant tips and tricks to optimize their content marketing based on their Facebook ads practice data from the last meeting. The trainers still checked the participants' progress to ensure that they comprehend the material well from the first week after training until five weeks later (5 August - 2 September 2020).

\section{RESULTS AND DISCUSSION}

In the first week, the trainer asked the trainees to bring the best collection of photos of their products and their products as materials for creating video content. In the firstweek training, MSMEs will learn Creating Videos and Developing Promotional Language. The first problem that trainers found is that the trainee does not know the standard appearance of good photos, so they take pictures anywhere, including on the kitchen floor, did not prepare the lighting, and the background, which will not be appealing to customer potentials. 


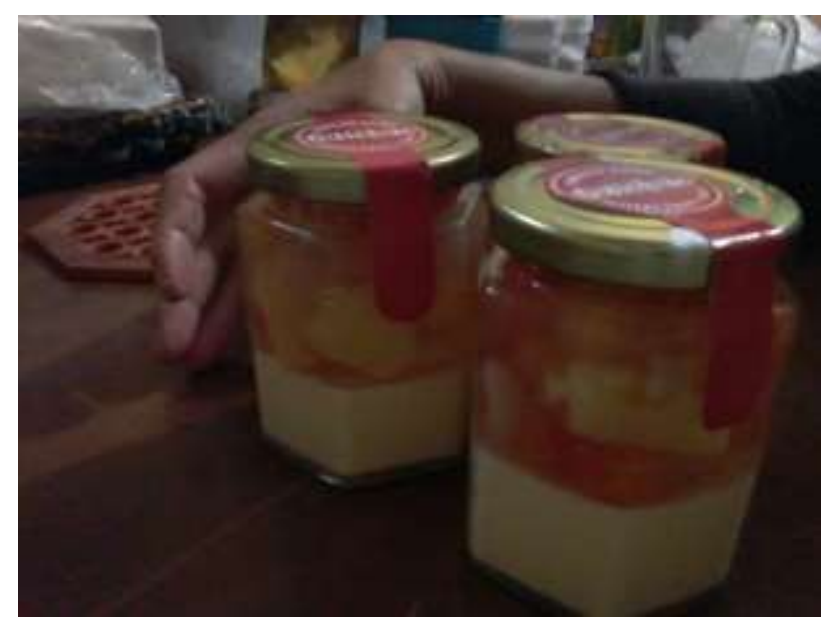

Figure 3. One of the participant Photo product, "Puding Buah Jar".

With most participants having similar problems in their photo products, the team trainer gave them quick tips to help them take their product picture with mini studio Photobox facilitated by RKB Telkom. Outstanding photoproduct is crucial because it will attract the potential customer. As we know, social media and market place are full of various product and different sellers; the visual of photos and video will make its differences in the game of attraction.

After correcting the participant photo product, the trainers guide them to make video promotion using their photos using the free Kinemaster application. Why don't we use photos instead of effort making a video? The data tell us that video makes more engagement than images (Dopson, 2019); the differences are 59.3\% video, $29.6 \%$ (images), and $11.1 \%$ said there is no difference.

The video alone is not that effective than pairing with a good caption. The trainers also guide the participant to write their captions that reflecting their product. An excellent caption is a word that communicates with the audience, Facebook lesson and Sprout Social gave us 15 points that can make our post have higher engaging, such as: Ask questions; telling a story, showing personality, sharing tips and trick, and many more (West, 2020). At this point, trainers found that the participant did not know the selling point of their product. Most of them make it and try to sell it because they can do so without further planning and product differentiation. This finding made the training more complicated because the participants did not recognize the product's strengths themselves, so they had nothing to share. At the end of the meeting, the trainers gave the participants homework to find advantages from their products and write it as a caption for next week's meeting. 
When properly aligned with product types, selling cues impact consumer purchase intention, and it is an expensive skill (Das et al., 2018; Ladeira et al., 2016).

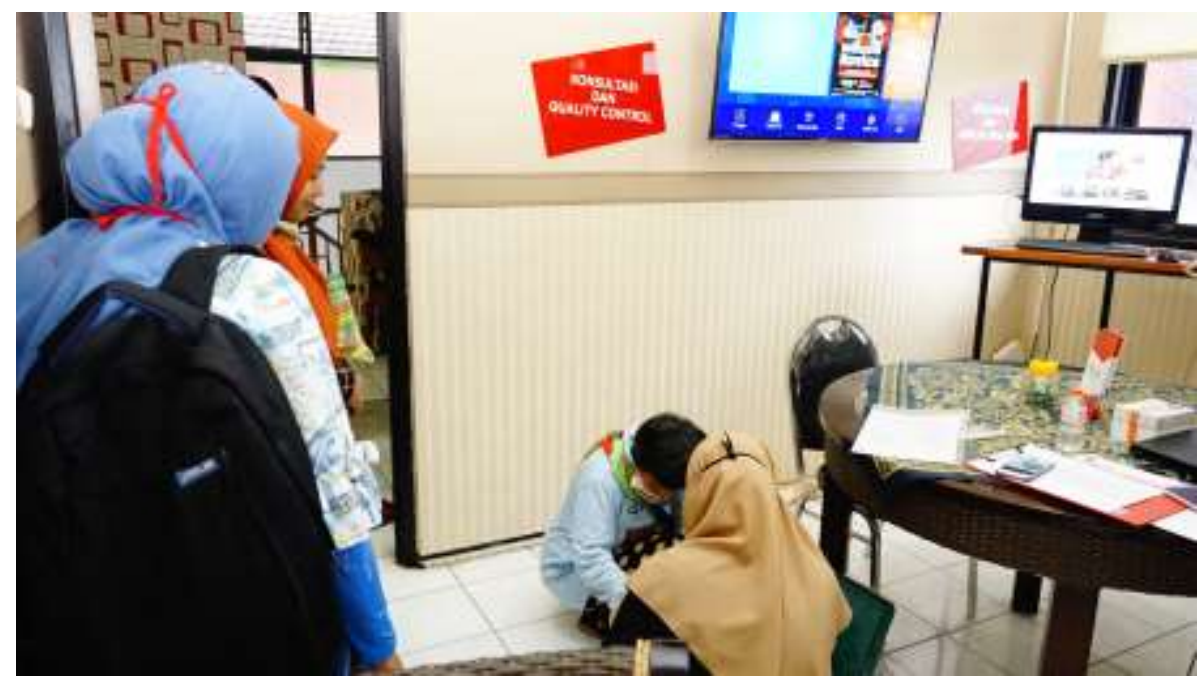

Figure 4. Digging product strengths from each trainee.

Participants learn about Facebook's digital marketing and advertising strategies in the second-week meeting, especially placing an advertisement on Facebook. Before placing the ads on Facebook, the video content and caption should be ready because they cannot go further if there is no content. It appears that only three trainees were ready and confident with their content, the other 12 still going the bush with their caption.

In that case, trainers split into two teams, the first-team helping the three MSMEs find their target market on Facebook ads; the other teams help the 12 with their various problems. In this second week of training, Trainers found that participants of different ages and industries bring about a wide variety of obstruction. The trainer did not imagine that they would experience obstacles because participants forgot their Facebook password. The other one, an older adult, insists that the best caption for his product is "great quality at the lowest price, and everyone can buy it." Which is would work in the targeted audience on Facebook. The more specific attributes will attract more potential buyers. The digital platform audience tends to search for specific words based on their need (Orasmäe, 2017). After an hour of participants' problem adjustment, the trainer decides that everyone learns about Facebook ads placement from the three ready-to-be advertised trainees. 


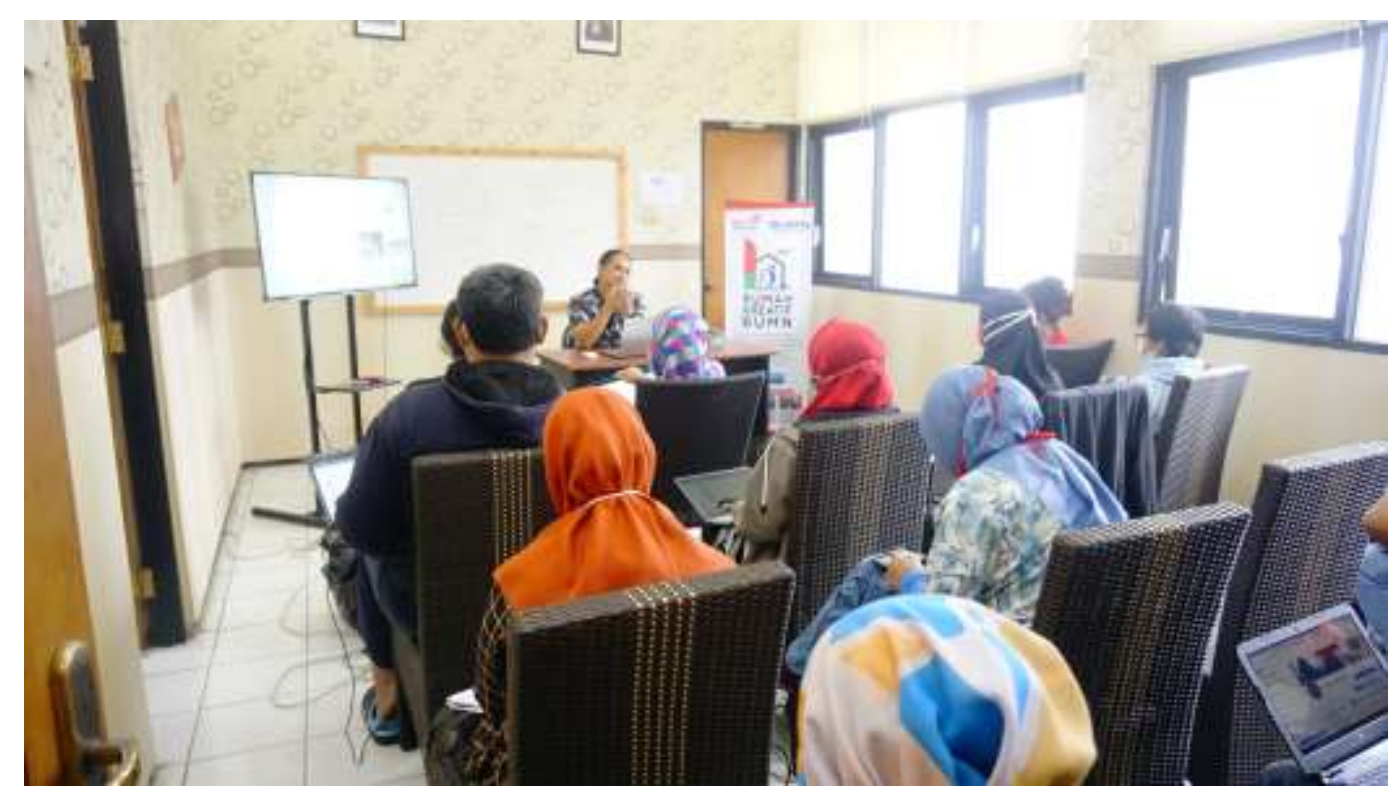

Figure 5. Training class of RKB Telkom Regency.

At the last meeting, the participant should learn about reading advertising data from Facebook Ads and compile more effective promotional messages. From three participant that was ready and confident with their content, only one of them has done the ad and got the report. The other two participants were still unsure about using the content they had to advertise. This unexpected finding made the trainers surprised because the participants should not be afraid to try placing their advertising on Facebook, considering that the fees paid later were a facility from the UMM's community service team.

The MSMEs condition that scares to take a risk that will cost them money is part of MSMEs' behavior. Most MSMEs are a family-owned business, and as a result, their objective is limited to maintaining their business activities (Kurniawati et al., 2019). Besides, their owners are afraid of debt, including using the money for advertising, which is a new activity in their daily businesses. This opinion also explains why the trainees are too careful in every step; it could be that they are trying to create ideal content to minimize the use of their capital.

Participants learn to analyze advertising data from "Kaveo Blog" as the only participant who produces ad data with this condition. "Kaveo Blog," owned by Ahmad Rizal, is a traditional cafe and selling coffee bean but using a coffee-blogger approach in his Facebook Page content. The "Kaveo Blog" Facebook advertising data show that, with spending Rp49.866,- the video content reaching 1.348 persons, 149-page likes, 130-video views, five-link clicks, with the cost per-likes Rp335,- which is a fair amount. In 2020 
research, the average Click Through Rate (CTR) is 4-5\% (Albright, 2020), with the average cost per click (CPC) global is $\$ 0.35$ (Lua, 2017) or Rp5.145- (IDR-USD 31 July 2020). With this data, trainers find that MSMEs' products can compete in the digital market if appropriately managed.

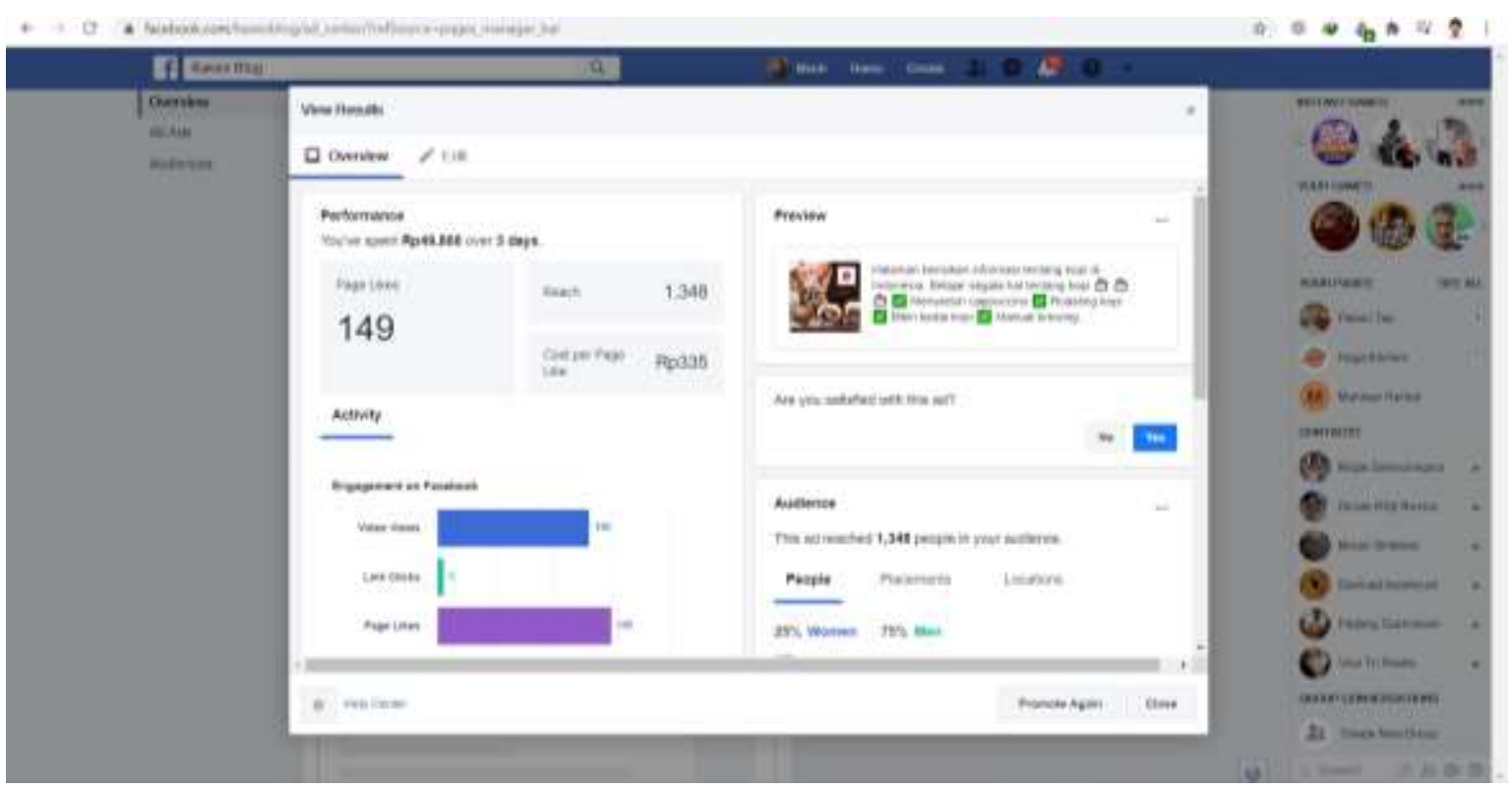

Figure 6. "Kaveo Blog" Facebook advertising data.

After reading and showing "Kaveo Blog" Facebook advertising data to the participants, trainers still try to guide the other 14 trainees to solve their problems and encourage them to try Facebook advertising. Even though the training session was switched into assistance in the WhatsApp group, most of the participants seemed unable to operate their devices properly because of a lack of digital literacy, so that in this last meeting, the trainer pursue that all participants were ready to upload. Even after five weeks of assistance in the WhatsApp group, just three of 15 trainees could place their content in Facebook ads.

\section{CONCLUSION}

Social media content marketing, as one of the digital marketing methods, should be working to gaining awareness, especially in the Covid-19 lockdown moment. The Indonesian behavior attached to a smartphone can make it easier for everyone to gain social media awareness, especially with relevant content. Training and assistance for MSMEs in Malang Regency show that the Indonesian Micro industry cannot create content marketing because of their low confidence to do something new, although the coach will 
bear the financial risk. The trainers find that business owner age affecting their digital literacy, but not their effort. Of three MSMEs that successfully place their content in Facebook ads, two are housewives with children and were born in the early 70 s. Even though the content is not yet ideal, their courage in posting the content provides the initial data needed to create more focused and ideal content. The other 12 that place their Facebook ads tend to look into ideal content before posting it, and it is challenging because producing content needs time, experience, and initial observation data.

The challenge from this training and assistance is that the participant has an extensive age and businesses, making the trainer work more to communicate set skills in content marketing. The future training should focus on specific participant and industry. Indonesian MSMEs need more academists to increase the capacity and ability to develop micro business.

\section{ACKNOWLEDGEMENT}

This paper and the research behind it would not have been possible without the exceptional support by the Communication Department, Faculty of social and political sciences University of Muhammadiyah Malang, and The BUMN Creative House (RKB) by Telkom Indonesia, Malang Regency.

\section{REFERENCES}

Albright, D. (2020). What's the Average CTR for Facebook Ads, and How Do You Improve It? https://databox.com/average-facebook-ctr

Das, G., Mukherjee, A., \& Smith, R.J. (2018). The Perfect Fit: The Moderating Role of Selling Cues on Hedonic and Utilitarian Product Types. Journal of Retailing, 94(2), 203-216. https://doi.org/10.1016/j.jretai.2017.12.002

Djatmiko, A., \& Pudyastiwi, E. (2020). Obstacles and Challenges of Indonesia's Micro, Small and Medium Enterprises (UMKM) in Facing the COVID-19 Pandemic. Jurnal Pendidikan Kewarganegaraan Undiksha, 8(1), 35-46. https://ejournal.undiksha.ac.id/index.php/JJPP/article/view/28610

Donthu, N., \& Gustafsson, A. (2020). Effects of COVID-19 on business and research. Journal of Business Research, 117, 284-289. https://www.ncbi.nlm.nih.gov/pmc/articles/PMC7280091/

Dopson, E. (2019). Videos vs. Images: Which Drives More Engagement in Facebook Ads? Databox. https://databox.com/videos-vs-images-in-facebook-ads, retrieved on 10 January 2021.

Hajarian, M., Camilleri, M.A., Díaz, P., \& Aedo, I. (2020). A Taxonomy of Online Marketing Methods. In Camilleri, M.A. (Ed.) Strategic Corporate Communication in the Digital Age, Emerald, Bingley, UK. 
Kurniawati, E., Chrissendy, M., \& Saputra, D. (2019). Behavioral factor influencing indonesian micro, small and medium (msme's) owners decision-making in adopting e-commerce. Journal of Entrepreneurship, Business and Economics, 7(1), 92-105.

Ladeira, W. J., Nique, W. M., Pinto, D. C., \& Borges, A. (2016). Running for pleasure or performance? How store attributes and hedonic product value influence consumer satisfaction. International Review of Retail, Distribution and Consumer Research, 26(5), 502-520. https://doi.org/10.1080/09593969.2016.1182934

Lua, A. (2017). How Much Does Facebook Advertising Cost? The Complete Guide to Facebook Ads Pricing. Buffer.

https://www.business2community.com/brandviews/buffer/much-facebookadvertising-cost-complete-guide-facebook-ads-pricing-01752363, retrieved on 10 January 2021.

OECD Secretary General. (2020). Covid-19: SME Policy Responses (Issue March). https://oecd.dam-broadcast.com/pm_7379_119_119680-di6h3qgi4x.pdf

Orasmäe, A. (2017). Integrated Marketing Communication. In Integrated Marketing Communication. https://doi.org/10.4324/9781315526812

Priambada, S. (2017). Potensi Media Sosial Bagi Usaha Kecil Dan Menengah (UKM) Di Malang Raya. Seminar Nasional Sistem Informasi Indonesia, November, 239-244.

Rahman, R. (2020). 37,000 SMEs hit by COVID-19 crisis as government prepares aid. The Jakarta Post, 4-7. https://www.thejakartapost.com/news/2020/04/16/37 000-smes-hitby-covid-19-crisis-as-government-prepares-aid.html.

Riveong, D.J., \& Rachmad, S.H. (2018). Internet Users, Market Target and Digital Trading of MSMEs in Indonesia Internet Users, Market Target and Digital Trading of MSMEs in Indonesia. IARIW General Conference, 1-12.

Kemp, S. (2020). Digital Data Indonesia 2020. In Data Reportal, We Are Social \& Hootsuite. https://datareportal.com/reports/digital-2020-indonesia, retrieved on 10 January 2021.

West, C. (2020). 15 Facebook post ideas to increase engagement. https://sproutsocial.com/insights/facebook-posting-tips/, retrieved on 10 January 2021.

(C) 2020 by authors. Content on this article is licensed under a Creative Commons Attribution 4.0 International license. (http://creativecommons.org/licenses/by/4.0/) 